\title{
Impact of the attributes of private tourist accommodation facilities onto prices: A hedonic price approach
}

\author{
Ana Portolan ${ }^{1 *}$
}

Received: 28/06/2012 Accepted: 01/10/2012

\footnotetext{
1 University of Dubrovnik, Department of Economy and Business Economy, Lapadska obala 7, 20000 , Dubrovnik, Croatia; tel: + 385 (0) 20445 936; fax: + 385 (0) 20445 940; e-mail: ana.portolan@unidu.hr

* Corresponding author
}

\begin{abstract}
The concept of private tourist accommodation has been insufficiently studied in tourism economics literature. It has been only marginally brought up along with the hotel accommodation in scientific papers within the last ten years. Private accommodation represents almost $50 \%$ of the total capacity in the structure of accommodation in Croatia. The main purpose of this paper is to examine the determinants of facility prices for private accommodation in one of the Croatian leading tourist destinations, Dubrovnik, through empirical research. Hedonic model is applied to analyse the role of different attributes in form of the overall price of representative sample of private accommodation facilities and to demonstrate how facility prices can be related to certain attributes of private accommodation. The explanatory variables of the overall price, among others, include location, characteristics such as availability of free parking place, distance to the Old Town, sea view, terrace/garden. The results of this research provide instructions and direction to main tourism stakeholders and policy makers, and at the same time assist facility owners in shaping prices helping them to create instruments for future planning.
\end{abstract}

(C) 2013 International University College. All rights reserved

Keywords: private tourist accommodation facilities, hedonic price model, Dubrovnik

Citation: Portolan, A. (2013). Impact of the attributes of private tourist accommodation facilities onto prices: A hedonic price approach. European Journal of Tourism Research 6(1), 74-82.

\section{Introduction}

A constant growth in tourist arrivals and overnights in private tourist accommodation within the last ten years indicates the necessity for a more dedicated and more constructive approach to this type of accommodation. However, it is one of the least studied compared with the amount of empirical evidence available on other types of accommodation (Petrić and Mimica, 2011; Salò and Garriga, 2011), especially hotels, mainly because of better data availability and reliability. In private accommodation capacities forms room, studio apartment, apartment and second-home in Croatia in 2011 a total of 20.7 million overnights was realised, which is $34.4 \%$ 
of total overnights (Croatian Bureau of Statistics, 2012).

This paper sets out to analyse the price difference between accommodation facilities in private tourist accommodation which are perceived not as a homogeneous product but as a heterogeneous tourism product made up of a series of constituent parts, i.e. a set of differential attributes.

Pricing is a very complex and demanding job under the influence of a series of controlled and uncontrolled variables (Vrtiprah and Pavlić, 2005, p. 1999) which brings out the necessity to analyse the determining factors of the overall price. Price of every product, including tourism product - in this case private accommodation, is the result of its total value, i.e. value of its attributes. Consequently, existence or nonexistence of certain attributes in an accommodation facility implies the impact onto overall price. Cost of overnight stay in a private accommodation facility in Croatia is not the result of the official categorisation of the facility. In theory there is a uniform quality of private accommodation supply because most of the private accommodation facilities are three star facilities, while in practice the situation is quite different (Petrić and Mimica, 2011). Accommodation facilities within a same category are equipped differently which creates the need to carry out a more detailed analysis of the attributes influencing the overall accommodation price.

It is assumed that the private tourist accommodation market will be well balanced if tourists optimise their choice based on the accommodation facilities attributes which they find more to their satisfaction, i.e. more useful. On the basis of this assumption the private accommodation price can be described as the function of accommodation facility attributes.

Determinants of private accommodation pricing at the Croatian accommodation market are scarcely known. Accommodation facilities within a same category and same equipped have different price. At the same time facilities within a same category and different equipped have identical price (www.dubrovnikapartments ource.com accessed on $20^{\text {th }}$ September 2012).
The main goal of this paper is to find out the major attributes that influence the overall prices of private tourism facilities using hedonic price methods. Therefore, in this article one of the most popular destinations in Croatia, Dubrovnik is analysed. In this local area, the market share of private accommodation is more than $48 \%$ of total beds. Primary data collected from a survey of 122 private tourism accommodation facilities during summer 2011 were used. The empirical research did not include accommodation facilities room and campsites in private accommodation. Rooms were excluded due to lack of satisfaction and enjoyment in a confined space, and there are no campsites in private accommodation in Dubrovnik.

Hedonic price theory is based on hypothesis that any goods or services can be observed as a bundle of characteristics or attributes and are valued for these attributes. The hedonic method literature in tourism has focused basically on hotels in tourist accommodation and holiday packages mainly because of better data availability and reliability. This paper is based on previous research on the impact of complex tourism product attributes onto overall price by hedonist price method within which non-hotel i.e. private accommodation was considered as a complex tourism product.

\section{Theoretical framework}

The term private accommodation originates from private ownership. Bronzan (2003) states that a much more acceptable term for private accommodation is private hospitality, for the simple reason since accommodation as a neutral word indicates roof over your head while hospitality has a significantly wider meaning and delivers the message that a much more personal approach is being offered. Users of the services and products cannot be offered a sole physical supply component such as autochthonous buildings and meals, but, to the contrary, the visitors must be conveyed the emotions, the pleasure, the intensive feeling of joy, as well as activities characteristic for the relevant area (Šostar et al, 2009). Hedonic experience is associated with pleasure and feelings. Motivation to travel is a hedonic motive relating to the feeling of joy when the motive has been satisfied (Kesić, 2006, p. 145). 
The hectic lifestyle and lack of spare time in the place of residence have lead to the loss of quiet family life and family atmosphere prompting tourists to seek in the place of their temporary residence i.e. during holidays the atmosphere and warmth of a home. As a consequence there is the continued growth in demand for quality, comfortable and fully equipped holiday homes, apartments and studio apartments, capable to offer the feeling of a home, togetherness and pleasure. These are all vital elements when offering the experience and satisfaction to tourists as well as in development of a destination and progress for the local community (Getz and Carlsen, 2005), consequently, they are constructive competition to hotel accommodation that must be strategically repositioned and managed according to the market requirements (Nuntsu et al, 2004) regardless the local affiliation (village or city). Analysis of private accommodation, in a different context, has been the focus of research of many scientists ((Warnick and Klar, 1991; Emerick and Emerick, 1994; Getz and Carlsen, 2000; Vasilevska-Nestoroska, 2001; Di Domenico and Lynch, 2007; Cerović et al, 2009; Mclntosh et al, 2011; Petrić i Mimica, 2011) who carried research on terminologically different but from the ownership, structural and functional point of view the similar forms of private tourist accommodation (bed \& breakfast, commercial home, family business). Their joint conclusions are that private tourist accommodation as an extensive and insufficiently utilised potential represents a quality foundation for:

$\checkmark$ reduction of unemployment and social tensions in a local community through selfemployment

$\checkmark$ utilisation of local resources and parallel protection of autochthonous products

$\checkmark$ reduction of hotel accommodation monopoly through faster adaptation, flexibility and innovativeness

$\checkmark$ realisation of new ideas, products and services

$\checkmark$ stopping population outflow

$\checkmark$ generating direct revenue for community members

$\checkmark$ avoiding the leakage of tourism revenue outside the region
Private accommodation in Croatia refers to accommodation units such as room, studio apartment, apartment, second-home and camp in private ownership, in which only accommodation is provided with a possibility of additional services such as breakfast, dinner etc.

Private accommodation was registered in Dubrovnik as early as the $14^{\text {th }}$ century when private owners accommodated foreigners in their houses with ready beds for them. In the $16^{\text {th }}$ century this form of accommodation absolutely prevailed and the authorities in Dubrovnik took special care to monitor these private accommodation premises making sure, under severe penalties that nothing immoral was going on there (Šubić, 2008).

Hedonic pricing attempts to take observations on the overall good (service) and obtain implicit prices for the individual components of the good (service) con-jointed. The earliest reference to the literature of hedonic price seems to be Waugh (1928). In his research which aimed at ascertaining how the consumers relatively value certain characteristics of a product, reached the conclusion that prices of some sorts of fresh vegetable vary depending on the Boston wholesale market and depending on various physical qualities of the vegetable. The term "hedonic pricing method" is generally attributed to Court (1939) who applied it to cars including several technical car qualities in the model. His work was renewed by Griliches (1961) applying it also to car industry in research of consumer preferences when choosing and buying cars. In 1960s Lancaster (1966) elaborated on the idea of approaching the product as a set of objective attributes rather than a homogeneous entity. Sherwin Rosen (1974) used a conventional utility-maximizing approach to derive implicit attribute prices for multi-attribute goods under conditions of perfect competition. The research on this subject found that hedonic rather than utilitarian attributes of a product explained greater amount of variation in prices (Rosen, 1974). Results of the research can especially be applied in tourism since the main motive for travel is the wish to enjoy and tourists are more prone to stronger perception of hedonic attributes of a tourist product in comparison 
with the utilitarian. Hedonic price analysis is widely used for different goods such as housing and property (Goodman, 1978; Freeman, 1979; Witte et al, 1979; Andersson, 2000; Goodman and Thibodeau, 2002; 2002), wine (Combris et al, 1997; Oczkowski, 1994; Nerlove, 1995; Sayer and Moohan, 2007), automobile (Court, 1939; Griliches, 1961), computer (Chow, 1967; Cole et al, 1986; Berndt and Griliches 1990).

First study using hedonic pricing in tourism is Hartman's (1989) application to the luxury hotels. A year after Carvell and Herrin (1990) examined the implicit prices of hotel amenities for hotels in San Francisco using actual room rates as the dependent variable and only distance from the hotel to Fisherman's Wharf as explanatory variable. In the same year there was a pioneer investigation on how attributes of holiday packages implicate on overall price by using hedonic pricing (Sinclair et al, 1990). A series of locally dispersed research on this subject followed whose authors analysed holiday packages from various points of view but using the identical hedonic price methodology (Aguiló et al, 2001; Papatheodorou, 2002; Sard, 2002; Haroutunian et al, 2005; Thrane, 2005; Mangion et al, 2005). After Hartman (1989) and Carvel and Herrin (1990) the analysis of hotel accommodation pricing was the focus of research of many other scientists (White and Mulligan, 2002; Espinet et al, 2003; Thrane, 2007; Hamilton, 2007; Andersson, 2010; Hung et al, 2010; Chen and Rothschild, 2010; Kushi and Caca, 2010). The authors involved in analysis of the impact of attributes onto overall price of a product or service which does not involve accommodation are Rigall-I-Torrent (2011) who observed the tourism product as a set of public and private attributes with an emphasis on public attributes, and Falk (2008) who investigated the relationship between lift ticket prices and factors that influence the quality of ski resorts.

Little research using hedonic pricing models has been done in the field of private accommodation. The hedonic pricing model in an analysis of non-hotel accommodation pricing was used by Monty and Skidmore (2003) in their research of bed and breakfast amenities, as well as Fleischer and Tchetchik
(2005) in the analysis of rural households. Only recently there has been some research works on accommodation units which, according to Croatian Catering Industry Law, are classified as private tourist accommodation with application of hedonic pricing method. Some of the few authors working on these topics are Hamilton (2007), who carried out research on the impact of coastal landscape on the price of seven different types of accommodation included, beside the hotels and guesthouses, bed and breakfast, rooms in private accommodation, holiday homes and flats, Saló and Garriga (2011), who analysed the secondhome rental market and Juaneda et al, (2011) who made a comparative analysis of hotels and apartments in private ownership using the hedonic pricing model.

\section{Methodology}

Since the tourist cannot create his own bundle of attributes he has to choose from a finite number of multi-attribute bundles, i.e. from a number of private accommodation units with different attributes. In this article a general model, in which the "product" of a given private accommodation facility $F$ is the embodiment of a set of attributes, was employed (Espinet at al, 2003), so that

$F_{i}=\left(q_{i 1}, q_{i 2}, q_{i 3}, \ldots, q_{i k}, \ldots, q_{i m}\right)$

where $i=1, \ldots, n$ indexes private accommodation facility and $q_{i k}(k=1, \ldots, m)$, each of its attributes. Because the overall price is assumed to be a function of its attributes, the hedonic price function for $F_{i}$ can be considered as follows:

$P_{i}=P\left(q_{i 1}, q_{i 2}, q_{i 3}, \ldots, q_{i k}, \ldots, q_{i m}\right)$

where the functional form of $P$ is assumed to be constant across facilities, though the contribution of each attribute may vary from one facility to another. This set of attributes determines the choices of consumers according to their utility. Therefore, the price of the goods can be broken down into the implicit prices of these attributes.

Ordinary Least Squares (OLS) regression or the related log-linear form have in prior hospitality or tourism applications mostly been 
used to estimate this type of hedonic price model (Thrane, 2007: 316). Following Rosen's (1974) advice and that of the previous researchers in this domain (Espinet et al, 2003; Thrane, 2007; Chen and Rothschild, 2010; Kushi and Caca, 2010, for hotel data; and Monty i Skidmore, 2003; Juaneda et al, 2011; Saló i Garriga, 2011, for other types of accommodation) log-linear specification for the pricing function was used instead of the linear one.

Standard rates of private accommodation facilities are usually advertised as a price for the whole amenities per night. The dependent variable is the monthly average price in $€$ per person in main bed (additional beds are skipped) per night in July and August due to the high seasonality in private accommodation. Since the log-linear form is used in this study to correct heteroskedasticity, LNPRICE is the natural logarithm of the monthly average price per person per night in July and August.

In line with the theoretical guidelines for selecting independent variables in hedonic price theory (Andersson, 2000) the variable selection was based on the previous studies. Table 1 presents the final list of the explanatory variables considered in this model and their definition. Variable star rating category was excluded from the model since in Croatia the pricing category of the accommodation unit in private tourist accommodation is not officially determined by the star category.

\section{Empirical results}

In this paper solely private accommodation facilities within the limits of the city of Dubrovnik from Kantafig to Sveti Jakov are analysed. In 2011 in that area total of 1138 providers of private accommodation were registered. Out of total 1138 providers $33.5 \%$ are in Montovjerna/Lapad, $17.8 \%$ in Pile/Kono, $17.6 \%$ in Old Town, $13.5 \%$ in Gruž and $17.6 \%$ in Ploče (Internal statistical data Dubrovnik Tourist Board, February 2012). The percentage of accommodation units in the sample corresponds geographically to the percentage in the total number of providers.

A stratified sample was used based on geographical criteria and random choice of accommodation units. Total 122 accommodation units were analysed, making $10.7 \%$ of the total number. The data were obtained from two Internet travel agents, Dubrovnik Apartment Source and Croatian Travel Agency and one portal (www.dubrovnikarea.com). Dubrovnik Apartment Source is considered as the best mediator in private tourist accommodation sales and their data are

Table 1. Description of variables used in the hedonic regression

\begin{tabular}{ll}
\hline Variable & Description of variable \\
\hline $\begin{array}{l}\text { Dependent variable } \\
\text { PRICE }\end{array}$ & $\begin{array}{l}\text { Rate per person in main bed per night in } € \\
\text { LOGPRICE }\end{array}$ \\
\hline Pxplanatory variable & Accommod \\
LOCATION & Availability of free parking place \\
PARK & Accommodation facility is located more than 500 m from beach \\
BEACHDIST & Sea view from the accommodation facility \\
SEAVIEW & There is a garden, terrace or balcony in the accommodation facility \\
GARD/TERR/BALC & There is air-conditioning and heating in the accommodation facility \\
AIRCON/HEAT & There is a satellite television in the accommodation facility \\
SATTV & There is a safe in the accommodation facility \\
SAFE & There is a video player in the accommodation facility \\
DVD player & There is a swimming pool in the accommodation facility \\
SWIMPOOL & There is Internet connection included in the price \\
Internet & There is a dish washer in the accommodation facility \\
DISHW & There is a washing machine in the accommodation facility \\
WASHM & There is a hair drier in the accommodation facility \\
HAIRD & There is an iron and ironing board in the accommodation facility \\
IRON &
\end{tabular}


Portolan, A. (2013) / European Journal of Tourism Research 6(1), 74-82.

Table 2. Hedonic price function for private accommodation in Dubrovnik

\begin{tabular}{|c|c|c|c|}
\hline & Coefficients & Std. Error & t-value \\
\hline Location & -0.104 & 0.043 & $-2.430^{\star * *}$ \\
\hline Parking & 0.399 & 0.142 & $2.811^{\star \star *}$ \\
\hline Distance to the beach & -0.056 & 0.034 & $-1.632^{*}$ \\
\hline Sea view & -0.035 & 0.126 & -0.281 \\
\hline Garden/terrace/balcony & 0.272 & 0.135 & $2.017^{\star *}$ \\
\hline Air-condition/heating & -0.756 & 0.484 & -1.564 \\
\hline SAT TV & -0.274 & 0.156 & -1.756 \\
\hline Safe & 0.038 & 0.216 & 0.176 \\
\hline DVD player & 0.222 & 0.140 & 1.592 \\
\hline Swimming pool & -0.700 & 0.350 & -1.998 \\
\hline Internet & -0.384 & 0.134 & -1.865 \\
\hline Dishwasher & -0.063 & 0.139 & -0.452 \\
\hline Washing machine & -0.245 & 0.130 & -1.884 \\
\hline Hair drier & -0.045 & 0.130 & -0.349 \\
\hline Iron/Ironing board & -0.118 & 0.153 & -0.772 \\
\hline F-value & $7.083^{\star \star}$ & & \\
\hline Adj. R-Squared & 0.501 & & \\
\hline
\end{tabular}

realistic and true. Their web site www.dubrovnikapartmentsource.com offers all required data on the prices, location of the accommodation unit, interior and exterior decoration as well as the percentage of capacity utilisation. From Croatian Travel Agency and Dubrovnik Area Online pages the data on accommodation units in the area of Gruž were collected since Dubrovnik Apartment Source does not offer any data on Gruž. The research period was limited to two summer months during which the largest number of arrivals and overnights in private tourist accommodation is realised, in order to avoid the problem of seasonality.

Explanatory power of the model is medium, explaining $50.1 \%$ of the variations in prices as measured by the adjusted $R^{2}$. The results indicate that only four attributes (location, parking, distance to the beach and garden/terrace/balcony) influence the prices of overnights in private accommodation in the city of Dubrovnik. The prices in accommodation units distant from the Old City are some 10.4\% lower than in those situated in the vicinity of the Old City. Overnight prices in accommodation units with parking included are 39.9\% higher than those not offering the same service. Prices in the accommodation units in private ownership in the vicinity of a beach are $5.6 \%$ higher than those that are more distant from a beach. Offers including garden/terrace/balcony within the accommodation units increase the price by $27.2 \%$. The conclusion may be reached that parking included in the rental price is by far the most influential factor in shaping the price. Having a terrace, garden or balcony satisfies the original hedonic motive for satisfaction and consequently the existence of these is of utmost importance in determining the price. All other variables involved in the analysis have no impact on the price in private tourist accommodation in the city of Dubrovnik.

Multicollinearity is often an issue in hedonic pricing model. Nonetheless, no definitive rules exist for determining whether multicollinearity is a serious problem in a particular hedonic application (Chen and Rothschild, 2010). In collinearity diagnostics eigenvalue and $\mathrm{Cl}$ (Condition Index) were used. Eigenvalue near zero and $\mathrm{Cl}$ higher than 15 are indicators of the presence of collinearity. In this analysis eigenvalue is not near zero and $\mathrm{Cl}$ is lower than 15 for all variables except for hair dryer (eigenvalue=0.032; $\mathrm{Cl}=18.159$ ) and iron and ironing board (eigenvalue=0.009; $\mathrm{Cl}=34.377$ ) which not influence the prices, suggesting that in this study multicollinearity is not a serious problem. Since the survey was geographically limited, the findings of this study are indicative rather than representative of the private accommodation as a whole. 
Impact of the attributes of private tourist accommodation facilities onto prices: A hedonic price approach.

\section{Conclusions}

Private accommodation facilities are one of the most important, but least exploited areas of the tourist accommodation market when compared with hotels. This type of accommodation is an alternative to hotels in Dubrovnik where the number of tourists is still increasing.

In order to investigate the importance of the chosen private accommodation attributes in determining the overall price in a private accommodation unit in Dubrovnik the hedonic pricing model was used.

The variables that have the most important effects on the final price of rented accommodation are location of private accommodation facility, parking, distance to the beach and garden/terrace/balcony.

The results of this research have the double role. They provide instructions and directions to main tourism stakeholders and policy makers, and at the same time assist facility owners in shaping prices helping them to create instruments for future planning.

This study has certain limitations. Due to data availability, the research focuses on the local private accommodation in Croatia. Since the empirical results are based on relatively small sample size, the findings should not be overgeneralised. To enhance the generalisability of the results, further investigation through empirical studies is required. A cross-regional comparison can be made to broaden the usefulness of the results. Further research also needs to explore the tourist evaluation of pricequality relationship and the implied willingnessto-pay for private accommodation facilities by using data collected directly from tourists employing the hedonic pricing model.

\section{References}

Aguiló, P.M., Alegre, J., \& Riera, A. (2001). Determinants of the price of German tourist packages on the island of Mallorca. Tourism Economics, 7(1), 5974.

Andersson, D.E. (2000). Hypothesis testing in hedonic price estimation - On the selection of independent variables. The
Annals of Regional Science, 34, 293304.

Andersson, D.E. (2010). Hotel attributes and hedonic prices: an analysis of internetbased transactions in Singapore's market for hotel rooms. The Annals of Regional Science, 44(2), 229-240.

Berndt, E.R., \& Grilitches, Z. (1990). Price indexes for microcomputers: An exploratory study. Working Paper no. 3378, Cambridge: National Bureau of Economic Research.

Bronzan, L., (2003), Kako obogatiti turistički proizvod privatnog smještaja u Hrvatskoj. Tourism, 51(1), 81-90.

Carvell, S.A., \& Herrin, W.E. (1990) Pricing in the hospitality industry: An implicit markets approach, Florida International University Hospitality Review, 8, 27-37.

Cerović, Z., Jurdana, D. S., \& Milohnic, I. (2010). Restructuring and repositioning of private accommodation in Primorsko-goranska county: problems and solutions. Tourism and Hospitality management, 16(1), 85-99.

Chen, C., \& Rothschild, R. (2010). An application of hedonic pricing analysis to the case of hotel rooms in Taipei, Tourism Economics, 16(3), 685-694.

Chow, G.C. (1967). Technological change and the demand for computers. American Economic Review, 57, 765-768.

Cole, R., Chen, Y.C., Barquin-Stolleman, J.A., Dulberger, E., Helvacian, N., \& Hodge, J. H. (1986). Quality-adjusted price indexes for computer processors and selected peripheral equipment, Survey of Current Business, 66(1), 1-50.

Combris, P., Lecocq, S., \& Visser, M. (1997). Estimation of a Hedonic Price Equation for Bordeaux Wine: Does Quality Matter? The Economic Journal, 107(441), 390-402.

Court, A.T. (1939). Hedonic price indexes with automotive examples. In The Dynamics of Automobile Demand. New York, The General Motors Corporation.

Croatian Bureau of Statistics (2012) Official website. URL: www.dzs.hr (Accessed on 7th March 2012.)

Di Domenico, M., \& Lynch, P.A. (2007) Host/Guest Encounters in the 
Commercial Home. Leisure Studies, 26(3), 321-338.

Emerick, R.E., \& Emerick, C. (1994). Profiling American Bed and Breakfast Accommodations. Journal of Travel Research, 32(4), 20-25.

Epple, D. (1987). Hedonic Prices and Implicit Markets: Estimating Demand and Supply Functions for Differentiated Products, The Journal of Political Economy, 95(1), 59-80.

Espinet, J.M., Saez, M., Coenders, G., \& Fluvià, M. (2003). Effect on prices of the attributes of holiday hotels: a hedonic prices approach, Tourism Economics, 9(2), 165-177.

Falk, M. (2008). A Hedonic Price Model for Ski Lift Tickets. Tourism Management, 29(6), 1172-1184.

Fleischer, A., \& Tchetchik, A. (2005). Does rural tourism benefit from agriculture? Tourism Management, 26(4), 493-501.

Freeman, A.M. (1979). Hedonic Prices, Property Values and Measuring Environmental Benefits: A Survey of the Issues. The Scandinavian Journal of Economics, 81(2), 154-173.

Getz, D., \& Carlsen J. (2000). Characteristics and goals of family and owneroperated business in the rural tourism and hospitality sectors. Tourism Management, 21(6), 547-560.

Getz, D., \& Carlsen J. (2005). Family business in tourism. Annals of Tourism Research, 32(1), 237-258.

Goodman, A.C. (1978) Hedonic Prices, Price Indices and Housing Markets. Journal of Urban Economics, 5, 471-484.

Goodman, A.C., \& Thibodeau T.G. (2003). Housing market segmentation and hedonic prediction accuracy. Journal of Housing Economics, 12(3), 181-201.

Griliches, Z. (1961). Hedonic price indexes for automobiles: An econometric analysis of quality change. In The Price Statistics of the Federal Government, UMI, 173-196.

Hamilton, J.M. (2007). Coastal landscape and the hedonic price of accommodation. Ecological Economics, 62(3-4), 594602.

Haroutunian, S. \& Pashardes, P. (2005) Using brochure information for the hedonic analysis of holiday packages, Tourism Economics, 11(1), 69-84.

Hung, W-T., Shang, J.-K., \& Wang, F.C. (2010). Pricing determinants in the hotel industry: Quantile regression analysis. International Journal of Hospitality Management, 29(3), 378384.

Juaneda, C., Raya, J. M., Sastre, F. (2011). Pricing the time and location of a stay at a hotel or apartment, Tourism Economics, 17(2), 321-338.

Kesić, T. (2006). Ponašanje potrošača, Opinio, Zagreb

Kushi, E., \& Caca, E. (2010). The determinants of room prices in Saranda hotels. Journal of Studies in Economics and Society, 2(1), 287-298.

Lancaster, K. (1966). A new approach to consumer theory. The Journal of Political Economy, 74(2), 132-157.

Malpezzi, S. (2008) Hedonic Pricing Models: A Selective and Applied Review. In T. O'Sullivan and K. Gibb (eds) Housing Economics and Public Policy. Oxford: Blackwell Science.

Mangion, M-L., Durbarry, R., Sinclair, M. T. (2005). Tourism competitiveness: price and quality. Tourism Economics, 11(1), 45-68.

Mclntosh, A.J., Lynchu, P., \& Sweeny, M. (2011). „My Home Is My Castle“: Defiance of the Commercial Homestay Host in Tourism. Journal of Travel Research, 50(5), 509-519.

Monty, B., \& Skidmore, M. (2003). Hedonic Pricing and Willingness to Pay for Bed and Breakfast Amenities in Southeast Wisconsin. Journal of Travel Research, 42(2), 195-199.

Nerlove, M. (1995). Hedonic price functions and the measurement of preferences: The case of Swedish wine. European Economic Review, 39(9), 1697-1716.

Nuntsu, N., Tassiopoulos, D., \& Haydam, N. (2004). The bed and breakfast market of Buffalo City (BC) South Africa: present status, constraints and success factors. Tourism Management, 25(4), 515-522.

Oczowski, E. (1994). A hedonic price function for Australian premium table wine. 
Impact of the attributes of private tourist accommodation facilities onto prices: A hedonic price approach.

Australian Journal of Agricultural Economics, 38(1), 93-110.

Papatheodorou, A. (2002). Exploring competitiveness in Mediterranean resorts. Tourism Economics, 8(2), 133150.

Petrić, L., \& Mimica, J. (2011). Guidelines for the development of private accommodation facilities as an important type of accommodation offered in the Republic of Croatia. Acta Turistica Nova, 5(1), 1-42.

Rigall-I-Torent, R., \& Fluvià, M. (2011). Managing tourism products and destinations embedding public good components: A hedonic approach. Tourism Management, 32(2), 244-255.

Rosen, S. (1974). Hedonic Prices and Implicit Markets: Product Differentiation in Pure Competition. The Journal of Political Economy, 82(1), 34-55.

Saló, A., \& Garriga, A. (2011). The secondhome rental market: a hedonic analysis of the effect of different characteristics and high-market-share intermediary on price. Tourism Economics, 17(5), 10171033.

Sard, M., Aguilo, E., \& Alegre, J. (2002). Analysis of package holiday prices in the Balearic Islands. Document de Treball, 40, Universitat de les Illes Balears.

Sayer, J., \& Moohan, J. (2007). An analysis and evaluation of hedonic price valuations in local leasehold office markets. Paper presented at the 13th Conference of the Pacific Rim Real Estate Society, 21-24 January 2007.

Sinclair, M., Clewer, A., \& Pack, A. (1990). Hedonic prices and the marketing of package holidays: The case of tourism resort in Malaga, In Marketing tourism places, ed. Ashworth, G. and Goodall, B., Routledge, London

Statistical data of Dubrovnik Tourist Board (February, 2012)

Šostar, M. (2009). Razvojna strategija obiteljskog gospodarstva, in Turizam i agroturizam u funkciji održivog razvitka. ed. Šimić, M.L., Sveučilište J.J. Strossmayera u Osijeku, Ekonomski fakultet u Osijeku, Osijek, 134-149.

Šubić, N. (2008). Dubrovački turizam od 1857 do 2005 godine. Znanstvena knjižnica Dubrovnik

Thrane, C. (2005). Hedonic Price Models and Sun-and-Beach Package Tours: The Norwegian Case. Journal of Travel Research, 43(3), 302-308.

Thrane, C. (2007). Examining the determinants of room rates for hotels in capital cities: The Oslo experience. Journal of Revenue and Pricing Management, 5(4), 315-323.

Waugh, F.V. (1928). Quality factors influencing vegetable prices. Journal of Farm Economics,10(2), 185-196.

White, P.J., \& Mulligan, G.F. (2002). Hedonic Estimates of Lodging Rates in the Four Corners Region, The Professional Geographer, 54(4), 533-544.

Witte, A.D., Sumka, H. J., \& Erekson, H. (1979). An Estimate of a Structural Hedonic Price Model of the Housing Market: An Application of Rosen's Theory of Implicit Markets, Econometrica, 47(5), 1151-1173

Vasilevska-Nestoroska, I. (2001). Privatni smještaj u Makedoniji - značajke kvaliteta usluga, Tourism, 49(1), 51-56.

Vrtiprah, V., \& Pavlić, I. (2005). Menadžerska ekonomija u hotelijerstvu. Sveučilište u Dubrovniku 